\title{
Participatory analysis of vulnerability to drought in three agro-pastoral communities in the West African Sahel
}

\author{
Augustine A. Ayantunde ${ }^{1 *}$, Matthew D. Turner ${ }^{2}$ and Adamou Kalilou ${ }^{3}$
}

\begin{abstract}
Drought is one of the major climatic hazards impacting on the various sectors including crop and livestock in the West African Sahel. Pastoral and agro-pastoral communities in the region are regularly affected by drought, with vulnerability differing with gender, age, wealth status (access to cropland and livestock endowment), geographic location, social networks, and previous exposure to drought. Effective interventions require regular monitoring of vulnerability to drought, for which various quantitative and qualitative approaches exist. Qualitative assessments of vulnerability rely on participatory approaches with emphasis on involvement of the local communities in the analysis of their vulnerability to climate-induced stresses. In this study, we used a participatory approach to assess the vulnerability of three agro-pastoral communities in Niger to drought. The specific objective of this study was to assess the strength and limitation of a participatory vulnerability approach using a case study. According to the respondents in all the study sites, the incidence of drought has become more frequent in the last three decades compared to previous decades (before 1970). The impacts of drought on livelihoods according to the participants included food shortage, famine, forced sale of livestock to buy grain, decimation of livestock herds, and massive exploitation of woody plant species. The main weakness of participatory vulnerability assessments is the scalability of findings, as they are often location-specific. Therefore, participatory assessment should be complemented with more rigorous quantitative approaches to enhance applicability of the results to other locations with similar contexts.
\end{abstract}

Keywords: Climate change; Vulnerability; Climatic hazards; Participatory approach; West African Sahel

\section{Background}

The social dimensions of climate change in African drylands have attracted significant attention within the international community. Having experienced a significant decline in rainfall since the late 1960s, the Sudano-Sahelian region represents an important case for understanding the vulnerability of pastoral and agro-pastoral peoples to recurrent drought. Multiple definitions of vulnerability exist in the literature (Watts and Bohle 1993; Luers 2005; Adger 2006; Cutter 2006; Eakin and Luers 2006; O’Brien et al. 2007; Vogel et al. 2007; Cannon and Muller-Mahn 2010; Miller et al. 2010; Turner 2010; Ribot 2011; Bassett and Fogelman 2013). O’Brien et al. (2007) have argued that

\footnotetext{
* Correspondence: a.ayantunde@cgiar.org

${ }^{1}$ International Livestock Research Institute (ILRI), c/o CIFOR, 06 BP 9478

Ouagadougou 06, Burkina Faso

Full list of author information is available at the end of the article
}

approaches to address climate change are very much shaped by how vulnerability is defined. Decontextualized stimulus-response understandings of vulnerability linked to ideas of adaptability and the hazards school - what O'Brien et al. (2007) describe as 'outcome vulnerability' lead to technical or institutional fixes as means to reduce vulnerability. Even those understandings that O'Brien et al. (2007) would assign to their second category - 'contextual vulnerability' - show tremendous variability.

One important conceptualization is the disaster pressure-and-release' model of Wisner et al. (2004) which incorporates understandings about the relationship between biophysical variability and production of the 'hazards approach' (e.g. Cutter 2006) as well as about how the social context shapes a more broadly defined vulnerability from the food security literature (e.g. Watts and Bohle 1993; Ribot 2011). From this

\section{Springer}


perspective, vulnerability is 'an aggregate measure of human welfare that expresses the degree to which a person, group or human-environment system is likely to be exposed to, adversely affected by, and unable to cope with, and recover from the impact of a hazard' (Wisner et al. 2004). This is an appropriate framework to better understand the differential vulnerabilities of pastoral and agro-pastoral households and communities in the Sudano-Sahelian region, whose vulnerability is determined by socially mediated access to resources which in turn is often influenced by rainfall variability. Livestock husbandry figures prominently for all rural peoples in the region, no matter their ethnic and productive (e.g. 'farmers' or 'herders') identities. At a fundamental level, unlike crop agriculture, livestock producers can respond to the spatial heterogeneity of vegetative production by moving livestock to where it has rained. Still, these household responses are shaped not only by household labour but also by community-level efforts to protect livestock corridors, water points, and pastures. Moreover, livestock serve as important stores of wealth that can be converted to muchneeded grain during times of hardship. Livestock and grain markets very much meditate these conversions however with livestock prices often declining with respect to grain prices during severe (and widespread) droughts.

In these ways, hazards approaches will point to the resilience of mobile pastoralism (Martin et al. 2014) while food security approaches will point to economic vulnerability of livestock owners during droughts (Sen 1981; Watts 2013). An approach such as the 'pressure-and-release' model that incorporates both is critical to understand how vulnerability is produced in agro-pastoral communities in Sudano-Sahelian West Africa. Moreover, given the importance of community-level factors in shaping resource access (e.g. markets, labour, pastures) (Agrawal et al. 2009), such assessments must be conducted not only at the level of individual households but also at the community level. These considerations suggest that drought vulnerability is strongly shaped by local contexts (Nielsen and Reenberg 2010a, b). Such contexts are best known by local community members in the region who have experienced recurrent drought over many decades. Therefore, there is a strong need to develop participatory vulnerability assessments that address both social and biophysical sources of vulnerability at household and community levels.

In this article, we report on the use of a participatory vulnerability assessment (PVA) approach, inspired by the pressure-and-release model (Wisner et al. 2004), in three agro-pastoral communities in Niger.

\section{Participatory vulnerability assessment}

Various approaches have been reported in assessing the nature of vulnerability of pastoral and agro-pastoral communities to climatic stress and other shocks (O’Brien et al. 2004; Wisner et al. 2004; ActionAid International 2005; Smit and Wandel 2006; Freeman et al. 2008) and how it is distributed socially (gender, age, wealth) and geographically (resource access, access to markets and climate). Vulnerability assessment can be quantitative, qualitative, or a combination of both, depending on the objectives, disciplinary orientation, and scale of analysis, and may entail identifying, documenting, quantifying, and ranking the vulnerabilities to different stresses or hazards in a community or a system (Freeman et al. 2008). Quantitative vulnerability assessment uses measurable characteristics or indicators to establish scores or indices to represent the degree of vulnerability of a system, community, region, or country. For example, Vulnerability Analysis and Mapping (VAM) of food (in)security was developed by the World Food Programme (WFP) and has been used for vulnerability analysis for Niger (WFP 2005). VAM uses a range of monitoring indicators including satellite imagery of rainfall and crops and food prices in local markets to establish the vulnerability of regions in a country to food deficit (WFP 2005). The weakness of VAM is that the indicators used are developed by 'experts' with little or no input from the affected communities. Similar approach was used by Freeman et al. (2008) to assess the vulnerability of livestock-based communities in Lesotho, Malawi, and Zambia to economic- or climate-induced shocks. Through this approach, different geographic locations and their varying degrees of food deficit were identified and characterized into 'hotspot' and 'non-hotspot' of food aid. Deressa et al. (2008) and Opiyo et al. (2014) also used vulnerability indices based on a set of indicators from the literatures to measure household's vulnerability to climate-induced stresses by farmers and pastoralists in Ethiopia and Kenya, respectively.

According to Adger (2006), vulnerability cannot be easily reduced to metrics and is not easily quantifiable because the experiential or perceptual dimensions of vulnerability cannot be easily measured. Hence, frameworks for measuring vulnerability should complement quantitative measurements with insights and perceptions of vulnerability based on stakeholder-led qualitative assessments (Adger 2006). Qualitative assessments of vulnerability rely on participatory approaches with emphasis on involvement of the local communities in the analysis of their vulnerability to climate-induced stresses or risks (Brockhaus et al. 2013; Prokopy et al. 2013). According to these authors, participatory approach is appropriate where the study aims to change the behaviour of the people regarding their response to climate-related hazards. Participatory vulnerability assessments use qualitative techniques such as focus group discussion, semi-structured interviews, open-ended 
discussion, community workshop, key informant interviews, and role playing games in assessing vulnerability at the household or community level (ActionAid International 2005; Eriksen et al. 2005; Prokopy et al. 2013). Sometimes, participatory approach may be combined with quantitative indicators, for example in participatory modelling local actors identify the most relevant issues related to their vulnerability to climate change to be considered as input variables to contextualize the generalized model (Asare-Kyei et al. 2015). Tools that are commonly used in participatory analysis of vulnerability include resource mapping to illustrate the potential or actual impact of climatic hazards like drought on the community resources, scoring of the degree of severity of climate hazard or risk faced, ranking of the importance of risk and coping strategies, historical timelines of climatic hazards, stories about historical experiences related to climate change, and conceptual mapping or mental models. Conceptual mapping is often used to assess farmers' perceptions of their vulnerability and adaptive capacity to climate change, and it entails identifying and linking causes to the problems with arrows (Tschakert 2006).

The strength of participatory assessments of vulnerability is that they focus on the experiences of people or communities that have been affected by climatic stress and other shocks and their specific contexts. To assess the experiences of the communities, key stakeholders are often engaged in an in-depth examination of their vulnerability. In participatory vulnerability assessments, the communities serve as both the informants and analysts (ActionAid International 2005). Sometimes, a facilitator may be required for the community workshop or focus group discussion to manage groups of people and effectively guide the discussion. In view of the strength of participatory vulnerability assessment as an approach to engage with the communities, it is commonly used by non-governmental organizations (NGOs) in developing countries to foster relations with communities and assist in the design and operations of interventions and development projects to reduce vulnerability to climatic hazards (ActionAid International 2005; van Aalst et al. 2008). This preference for the participatory vulnerability approaches by the NGOs has led to their increased use in vulnerability studies in the developing countries (van Aalst et al. 2008). However, there is presently paucity of information on the vulnerability analysis approaches in West African Sahel.

Tschakert (2006) used participatory risk ranking and scoring among smallholder farmers in Central Senegal with focus on multiple stresses such as low agricultural productivity, poor health, rural unemployment, loss of livestock, and food insecurity. This author did not include climatic hazards in his study. Brockhaus et al.
(2013) also used participatory approach to assess responses of agro-pastoralists in Northern Mali to external events such as droughts, the coping and adapting strategies of forest- and livestock-based livelihoods facing ecological changes. To identify and assess participants' responses to multiple climate- and livelihood-related stresses, these authors used a range of tools from participatory rural appraisal (PRA), such as fodder calendars, resource maps, and historical timelines. Roudier et al. (2014) reported participatory research in two communities in Senegal to assess the role of climate forecasts in smallholder agriculture using participatory modelling approach to integrate local and scientific knowledge. In an attempt to address the paucity of information in the Sahel on participatory vulnerability approaches, Ricci et al. (2015) developed a participatory risk management framework for local actors based on the UN Habitat Cities and Climate Change Initiatives (CCCI) in BoboDioulasso, Burkina Faso. However, this framework has not been applied by the authors and thus remains theoretical. The first three studies mentioned above focused on multiple stresses or hazards, and it is difficult to design community actions for multiple hazards. Besides, detailed vulnerability analysis requires context specificity and focus on clearly identified climatic hazard or stress (Rurinda et al. 2014).

In an attempt to fill the gap identified in few studies mentioned above on participatory vulnerability approaches in the Sahel, this study focused on participatory assessment of vulnerability of agro-pastoral communities in Niger to drought, which is one of the major climatic hazards in the Sahel. In addition, this study looked at the limitations (along with strengths) of participatory vulnerability assessments which are often overlooked by the NGOs who commonly used these approaches as they (the weaknesses) have implications for the scaling up of the findings. The specific objective of this study was to assess the strength and limitation of participatory vulnerability approach using a case study of vulnerability to drought in three agro-pastoral communities in Niger.

\section{Study area}

This study was conducted in three communities in Niger, namely Fakara, Gabi, and Zermou, with different rainfall, social, and economic conditions (Saqalli 2008; Saqalli et al. 2011, 2013). At all sites, climate is tropical semi-arid with rains distributed in one single rainy season from June to October. Average annual rainfall increases from the north to the south with Zermou in the north having on average $350 \mathrm{~mm}$ (Table 1) and Fakara $500 \mathrm{~mm}$ and Gabi to the south with around $550 \mathrm{~mm}$ of rainfall per year (Saqalli 2008). Soil fertility is relatively good in Gabi whereas it is average in Fakara and Zermou 
Table 1 Main features of the study sites

\begin{tabular}{llll}
\hline Feature & Fakara & Gabi & Zermou \\
\hline Location & Tillabery region, Western Niger & Maradi region, Central Niger & Zinder region, Eastern Niger \\
Nearest urban market & Niamey (about $80 \mathrm{~km}$ ) & Maradi (about $40 \mathrm{~km}$ ) & Zinder (about $40 \mathrm{~km}$ ) \\
Annual precipitation & $450 \mathrm{~mm}$ (range: 180 to 675) & $550 \mathrm{~mm}$ (range: 275 to 775$)$ & $350 \mathrm{~mm}$ (range: 70 to 525) \\
Dominant ethnic group & Djerma & Hausa & Hausa \\
Other ethnic group & Fulani & Fulani, Bouzou ${ }^{\mathrm{a}}$ & Fulani \\
Soil fertility (physical and chemical properties) & Poor/average & Good & Millet, sorghum, cowpea \\
Major crops & Millet, cowpea & Millet, sorghum, cowpea & Medium \\
Degree of crop-livestock integration & Medium & High & 5.19 \\
Household size (adult equivalent) & 6.48 & 7.03 & 2.89 \\
No. of livestock owned (TLU per household) & 4.67 & 2.67 & $32 \%$ \\
Education level & & & $17 \%$ \\
$\quad-$ Illiterate (not able to read or write) & $60 \%$ & $56 \%$ & $3 \%$ \\
$\quad-$ Primary school & $15 \%$ & $17 \%$ & $48 \%$ \\
\hline
\end{tabular}

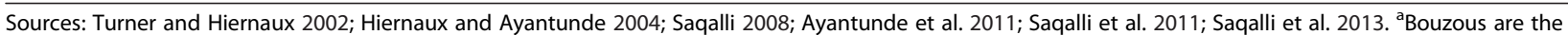
descendants of Tuareg slaves and freed during the colonization. They still keep large elements of Tuareg culture and keep mainly livestock

(Table 1). Millet, sorghum, and cowpea are the major crops while cattle, sheep, and goats are the dominant livestock species in the three study sites. The WFP report on food security in Niger of 2005 (WFP 2005) ranked Fakara and Zermou highly vulnerable to drought and food insecurity.

Fakara is situated in southwestern Niger (Kollo administrative district), and it lies between the confluent valleys of the Niger River to the west and the fossil valley of the Dallol Bosso to the east. Fakara is about $70 \mathrm{~km}$ northeast of Niamey, Niger's capital. The study site, which has been described in detail by Turner and Hiernaux (2002), Hiernaux and Ayantunde (2004), and Ayantunde et al. (2011), is populated mainly by the Djerma ethnic group. While historically crop cultivators, many Djermas increasingly rely on livestock, which follows the regional trend towards mixed farming systems, blurring the dichotomy between ethnicities who traditionally based their livelihoods uniquely on either livestock owning or crop cultivation, a trend which is driven by the need for diversification to reduce vulnerability. Fakara also harbours a significant number of Fulani people (about $20 \%$ of the population of the study site), who are pastoralists but are increasingly engaged in farming. According to the survey conducted in 2004 (Ayantunde et al. 2007), about $90 \%$ of the Fulani households in Fakara were also growing crops in addition to livestock husbandry. Since the droughts of the 1970s, livestock-poor pastoralists are increasingly farming on land that is usually leased to them by farmers holding usufruct and there are many poor Fulani in Niger who have abandoned pastoralism to take up farming (Moritz et al. 2009).

Gabi is situated $40 \mathrm{~km}$ to the south of Maradi, the second major town of the country and is less than $30 \mathrm{~km}$ away from the border with Nigeria. Devoid of hardened plateaus or stony hills, it is crossed by a dry valley (called the Goulbi of Gabi) oriented south-north (Saqalli 2008). The Gabi site is mainly populated by Hausa, with a minority of Fulani and Bouzou who have sedentarized. The Gabi site has been described in detail in studies on farming system transitions by Mortimore et al. (2001) and Tiffen (2001). There is a high integration of crop and livestock farming in Gabi as is the case in most communities in the Maradi region of Niger (Saqalli 2008). Due to good soil fertility and extensive use of animal manure and fertilizers in Gabi, millet yield is relatively higher than those of Fakara and Zermou sites in a normal rainfall year. Due to its closeness to Katsina and Kano, two major towns in the north of Nigeria, many households in Gabi have family members who work there as migrant labourers or as small-scale traders. These migrant family members provide an important source of revenue to many households in Gabi.

Zermou is situated $40 \mathrm{~km}$ northeast of Zinder, the third biggest town in Niger. It is characterized by countryside of rocky inselbergs and stony granite or metamorphic hills (Saqalli 2008) which constitute, depending on the villages, around $30 \%$ of the territory. The rocky and stony areas in the territory are used as grazing areas since they cannot be cropped. The rest of the territory is almost entirely covered by a sandy plain, constituting the major part of millet-cropped areas with sandier soils 
than in the Fakara. The presence of sand favours drainage but in case of low rains increases the risk of poor yields. Due to low soil fertility and low rainfall, Zermou has been highly vulnerable to food insecurity in the last three decades and has suffered many famines; the last one was in 2005 (Saqalli 2008; Saqalli et al. 2013). The major ethnic group in Zermou is Hausa with a mixed origin of Kanuri/Hausa while Fulani ethnic group is in minority. In all the three study sites, Koranic education is an important form of education. The illiteracy rate is quite high in Fakara and Gabi (Table 1).

\section{Methods}

\section{Data collection}

For the community workshop and focus group discussion, a range of tools from participatory rural appraisal were used such as historical timelines, seasonal calendars, and matrix scoring and ranking. In each site, a facilitator who speaks the local language very well (Zarma in Fakara, Hausa in Gabi and Zermou) moderated the community workshop and focus group discussion. The facilitator guided the discussion by posing questions to the participants on different issues on vulnerability to drought and ensured their active participation. For each question, about five participants were allowed to speak including at least a woman, and this was then approved by the participants at the community workshop by waving of hands. When two or more responses were different, the participants were asked to show the response they supported by raising their hands and they were counted. For most of the questions, there was unanimous support for the responses by the participants. Differences in response were only noted for the question on severity of drought, particularly for the drought considered modest by the majority of the participants (that is $>75 \%$ ). To classify the severity of drought, we used a scoring tool where four pebbles denoted very severe, three pebbles for severe, two pebbles for modest, and one pebble for mild. The facilitator was assisted by two rapporteurs who were responsible for taking notes from the discussions. The facilitators and the rapporteurs were from the project team, and they have been trained in the use of participatory vulnerability analysis (PVA) framework. To recognize the customary authorities in each study site, the village chief was appointed as chairman at the community workshop, and he was essentially responsible for giving the opening and closing speeches.

\section{Participatory vulnerability assessments}

A community-level workshop coupled with discussions with key informants were organized at each site between July and August 2008 using the PVA framework developed by ActionAid International (2005) to assess the vulnerability of the communities to drought. Participatory vulnerability analysis is a qualitative way of analysing vulnerability, which involves participation of exposed people.

The analytical framework for PVA is presented in Fig. 1 and it entails four steps (ActionAid International 2005). The first step is diagnosis of vulnerability of the community to climatic hazards, particularly drought. This involves identification of stakeholders and timeline analysis of the disasters the community has faced. To elicit necessary information, the participants were asked to identify climatic hazards, particularly drought, the community has faced, the time they occurred, and the frequency. Though the focus of the vulnerability assessment is on climatic shocks, nonclimatic-related hazards were mentioned in the course of the workshop in all the study sites and they were equally discussed. The second step of the PVA framework is the analysis of the causes of vulnerability - the underlying causes, severity, and ranking the list of causes. The third step is the analysis of community actions and capacity. This entails establishing the existing strategies, resources, and assets used to reduce vulnerability and external assistance received and their effectiveness. The fourth step is identifying interventions from the analysis which entails prioritizing broad interventions including actions to be carried out by the communities and those by the external agencies.

\section{Stakeholders' participation}

The success of participatory vulnerability analysis partly relies on the diversity of stakeholders involved (ActionAid International 2005). For the community workshop in each study site, we invited key community leaders, local government officials, non-governmental organizations, governmental organizations, and agricultural research institutions. All social groups, defined by ethnicity/caste/occupation in each community were represented at the workshop. The village head in each community and local government chairman participated at the workshop. The number of adults who participated in Fakara, Gabi, and Zermou was 101,168 , and 125, respectively, with all ethnic groups represented - Hausa, Djerma, Fulani, and Bouzou. About 40 \% of the workshop participants in each site were women. Participation by local government officials, government ministries, and NGOs provided a unique opportunity of linking the local communities with the key actors in relief services and disaster response. In each community, the workshop started with brief introduction of the project and presentation of procedures for the workshop. This was then followed by group work to construct a timeline of the disasters, especially climate related, that the community has faced. Afterwards, the discussion moved on to the participants' understanding and analysis of vulnerability. Community actions taken in response to drought and external assistance received were also discussed as well as necessary actions to be better prepared for future climatic shocks. After the workshop, a focus group discussion consisting 


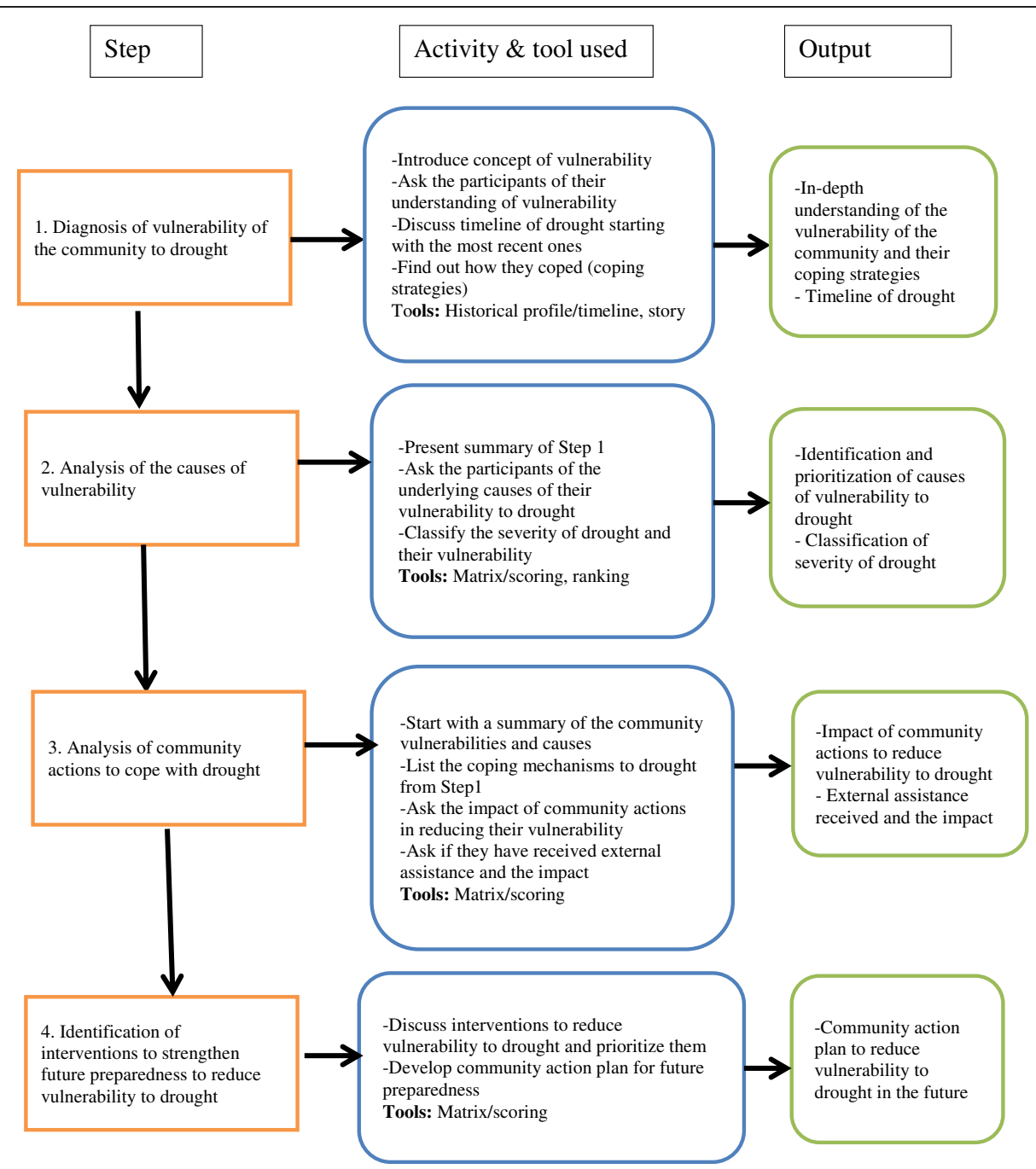

Fig. 1 Analytical framework for participatory vulnerability analysis (adapted from ActionAid International 2005)

about ten key informants (including community leaders, government representative, NGO staff, and a researcher) was held in each community to validate the results from the workshop. This validation was guided by two major questions: Are the results consistent with the actual situations in the community and if not, why? Is there any key information missing from the results? Most of the results from the community workshop were judged to be reliable by the focus group discussants.

\section{Results and discussion}

Timeline, frequency, and impact of drought on livelihoods According to the timelines of drought ${ }^{1}$ incidents prepared by the workshop participants, drought occurred at least once in a decade in all the study sites since 1950 (Table 2) but with varied degrees of severity. The common features of drought included insufficient rainfall, late onset of rainfall, and early cessation of rainfall especially during millet flowering (Table 2) which led to poor-to-non-existent crop yield and scarcity of forage resources for livestock. The impacts of drought on livelihoods according to the participants included food shortage, famine, forced sale of livestock to buy grains, decimation of livestock herds, increased exploitation of woody plant cover, and migration of young men to neighbouring countries. The timeline of drought incidents mentioned by the workshop participants largely agrees with the report by Brooks (2004) who observed that about eight major droughts have occurred in semiarid Africa since 1960. The major droughts of 1973/ 1974 and 1983/1984 in West African Sahel (Turner 2000; Brooks 2004) were mentioned by the participants in all the sites. Six droughts were mentioned in both Fakara and Gabi since 1950 whereas eight droughts were mentioned in Zermou during the same period confirming the assessment by the World Food Programme 
Table 2 Timeline of drought incidents in the study sites and the impact on livelihoods of the community

\begin{tabular}{|c|c|c|c|c|}
\hline$\overline{\text { Site }}$ & Year & Feature & Severity & Impact on livelihood \\
\hline \multirow[t]{6}{*}{ Fakara } & 1954 & Very late onset of rainfall & Modest & Poor crop yield and food shortage \\
\hline & 1966 & Early cessation of rainfall & Severe & Loss of crops and famine \\
\hline & $\begin{array}{l}1973 / \\
1974\end{array}$ & $\begin{array}{l}\text { Early onset of rainfall and sudden cessation while } \\
\text { millets were flowering }\end{array}$ & Severe & Sales of livestock at a very low price to buy grains \\
\hline & 1984 & Insufficient and early cessation of rainfall & Severe & $\begin{array}{l}\text { Total loss of crops, food shortage, sales of livestock to buy grains, } \\
\text { and migration }\end{array}$ \\
\hline & $\begin{array}{l}1997 \\
\text { to } \\
1998\end{array}$ & $\begin{array}{l}\text { Sudden cessation of rainfall when millets were } \\
\text { flowering }\end{array}$ & Modest & $\begin{array}{l}\text { Sales of livestock to buy grains and migration of young men to } \\
\text { neighbouring countries }\end{array}$ \\
\hline & 2005 & Insufficient rainfall leading to poor crop yield & $\begin{array}{l}\text { Very } \\
\text { severe }\end{array}$ & $\begin{array}{l}\text { Sales of livestock at a very low price to buy grains, a bull was sold } \\
\text { for as low as } 2000 \text { FCFA (about } \$ 4 \text { ), massive exploitation of forest } \\
\text { resources and massive migration }\end{array}$ \\
\hline \multirow[t]{6}{*}{ Gabi } & 1953 & Insufficient rainfall & Modest & Poor crop yield \\
\hline & 1962 & Insufficient and sudden cessation of rainfall & Severe & Widespread famine in the region \\
\hline & $\begin{array}{l}1973 \\
\text { to } \\
1974\end{array}$ & Insufficient rainfall & Modest & Migration to neighbouring countries \\
\hline & 1984 & Insufficient rainfall and early cessation of rainfall & $\begin{array}{l}\text { Very } \\
\text { severe }\end{array}$ & Poor crop yield and death of many animals \\
\hline & 1997 & Insufficient rainfall and early cessation of rainfall & Modest & Sales of livestock to buy grains \\
\hline & 2005 & Insufficient rainfall and early cessation of rainfall & $\begin{array}{l}\text { Very } \\
\text { severe }\end{array}$ & Poor crop yield, malnutrition, and sales of livestock \\
\hline \multirow[t]{8}{*}{ Zermou } & 1953 & Insufficient rainfall leading to poor crop yield & $\begin{array}{l}\text { Very } \\
\text { severe }\end{array}$ & Sales of livestock at a low price to buy grains \\
\hline & 1958 & Cessation of rainfall during the flowering of millet & Severe & Poor crop yield and sales of livestock to buy grains \\
\hline & 1973 & Sudden cessation of rainfall and insufficient rainfall & $\begin{array}{l}\text { Very } \\
\text { severe }\end{array}$ & Sales of livestock to buy grains \\
\hline & $\begin{array}{l}1983 \\
\text { to } \\
1984\end{array}$ & Cessation of rainfall during the flowering of millet & $\begin{array}{l}\text { Very } \\
\text { severe }\end{array}$ & Poor crop yield and sales of livestock to buy grains \\
\hline & 1986 & Insufficient rainfall & Severe & Sales of livestock to buy grains \\
\hline & 1997 & Insufficient rainfall & Severe & Sales of livestock to buy grains \\
\hline & 1999 & $\begin{array}{l}\text { Too much rain at the beginning of the season } \\
\text { followed by cessation of rainfall while crops were } \\
\text { growing }\end{array}$ & Severe & $\begin{array}{l}\text { Loss of animals due to feed scarcity and sales of livestock and } \\
\text { household properties to buy food }\end{array}$ \\
\hline & 2005 & Sudden cessation of rainfall and insufficient rainfall & Severe & Sales of livestock to buy grains \\
\hline
\end{tabular}

(WFP 2005) that the Zinder region, where Zermou is situated, is highly vulnerable to climatic shocks and food insecurity.

Over the past three decades, droughts are more frequent than previously (pre-1970) according to the respondents in all the study sites, and the communities are more vulnerable now due to repeated exposure to drought and the associated erosion of their adaptive capacity. The respondents in Gabi even said that drought tended to occur once every five years, but this observation was not confirmed by their response in terms of timeline of drought incidents (Table 2). However, the general perception of the increased frequency of drought by the workshop participants agrees with reports by UNEP (2002) and Thornton et al. (2009) that drought is likely to become more frequent and more severe in the Sahel as a result of global climate change.

In all the three sites, children, women, and elderly people were reported to be the groups most vulnerable to droughts. Poor households without livestock were also mentioned as vulnerable to droughts as they had no means to buy grain to meet food deficits. The participants' response agrees with the World Food Programme's report on food security in Niger (WFP 2005) which observed that groups vulnerable to drought and food insecurity are generally farmers with small farm size, livestock keepers with small herds, sedentarized pastoralists having few animals, households with large family size, and female-headed households. Livestock as a store of wealth play an important role in drought 
mitigation and risk coping strategies of pastoral/agropastoral households (Turner 2000).

\section{Community actions and external assistance in response to drought}

The major coping strategies of the agro-pastoral communities in the study sites in response to droughts included harvesting of wild plants, sales of livestock to buy grain, migration to nearby towns or neighbouring countries (Nigeria for those in Gabi and Zermou), and help from relations (Table 3). The coping measures to droughts were similar in all the three sites. However, it has to be emphasized that coping strategies change over time as households modify or change their livelihood options (Campbell 1999). The response from the workshop participants shows that a wide range of coping options exists in the agro-pastoral communities even though their effectiveness may vary with the severity of drought (Campbell 1999; Turner 2000). These coping measures were generally seen by the participants as ineffective when faced with severe droughts. The reason for ineffectiveness of these community actions was also attributed to increased frequency of droughts between the past two decades which had weakened their ability to cope as the three communities had experienced at least two droughts (1997 and 2005) in the past 10 years (Table 2).

In all the three sites, government interventions, largely in the form of food aid, were seen by participants as important in enhancing their ability to cope with the impacts of droughts (Table 3). Food aid by the national government consisted of distribution of a few bags of cereals (mainly millet, sorghum, and maize) to the affected households. Most of the food aid by the national government was donated by the foreign governments, particularly in the case of the severe drought of 2005 in Niger. However, food aid by the government is not always regular and is often not well targeted, largely due to dependence of the government on foreign donations and government bureaucracy in the distribution of aid. Another major problem with government assistance in coping with droughts in pastoral and agro-pastoral communities is that it is often reactive and mainly focused on relief service (Barton et al. 2001) for those made destitute by drought, which suggests absence of a long-term national adaptation plan and financing mechanisms in coping with the impacts of climate change. According to the workshop participants, drought-related assistance from NGOs to the communities was minimal or none except for the drought of 2005 (Table 3) which attracted worldwide attention due to its severity.

\section{Future preparedness to reduce vulnerability to drought}

Community actions as well as external interventions in advance of any major hazard are both necessary to minimize the impact of drought and other climaterelated shocks. During the workshop, the participants in each study site were asked to identify community actions as well as external assistance that will enhance their future preparedness to reduce their vulnerability. To reduce vulnerability to future drought, the participants suggested expansion of cultivated land, off-season farming, small ruminant husbandry, application of fertilizers, adoption of improved and drought-tolerant crop varieties, and reclamation of degraded land. From these suggested community

Table 3 Community actions taken and external assistance received in coping with drought in the study sites

\begin{tabular}{|c|c|c|c|c|c|c|}
\hline Site & Community action & Effect & Government assistance & Effect & Assistance from NGOs & Effect \\
\hline Fakara & $\begin{array}{l}\text { Sales of livestock to buy } \\
\text { grains, harvesting of wild } \\
\text { plants for food, working as } \\
\text { casual labourers in nearby } \\
\text { towns, help from relations, } \\
\text { sales of household properties }\end{array}$ & $\begin{array}{l}\text { Not really } \\
\text { effective } \\
\text { in coping } \\
\text { with } \\
\text { severe } \\
\text { droughts }\end{array}$ & $\begin{array}{l}\text { Food aid - few bags of millet, } \\
\text { sorghum, and maize were } \\
\text { given to each household and } \\
\text { few bottles of cooking oil }\end{array}$ & $\begin{array}{l}\text { Very effective in } \\
\text { coping but not } \\
\text { regular }\end{array}$ & None & None \\
\hline Gabi & $\begin{array}{l}\text { Harvesting of wild plants for } \\
\text { food, sales of livestock to buy } \\
\text { grains, migration of young } \\
\text { men to work in Nigeria, help } \\
\text { from relations, and sales of } \\
\text { household properties }\end{array}$ & $\begin{array}{l}\text { Not } \\
\text { effective } \\
\text { when } \\
\text { faced with } \\
\text { severe } \\
\text { droughts }\end{array}$ & $\begin{array}{l}\text { Food aid - few bags of } \\
\text { sorghum and maize were } \\
\text { given to each household and } \\
\text { few bottles of cooking oil and } \\
\text { biscuits. One bag of wheat } \\
\text { flour and few bags of rice } \\
\text { were distributed to each } \\
\text { household during the drought } \\
\text { of } 2005 \text { along with powder } \\
\text { milk and salt }\end{array}$ & $\begin{array}{l}\text { Very effective in } \\
\text { coping but most } \\
\text { households sold the } \\
\text { bags of rice and } \\
\text { wheat flour to buy } \\
\text { sorghum }\end{array}$ & $\begin{array}{l}\text { MSF (Médecins Sans } \\
\text { Frontière) distributed powder } \\
\text { milk, bottles of cooking oil, } \\
\text { and fortified biscuits. } \\
\text { Malnourished children were } \\
\text { fed at MSF feeding centre }\end{array}$ & $\begin{array}{l}\text { Very } \\
\text { effective }\end{array}$ \\
\hline Zermou & $\begin{array}{l}\text { Harvesting of wild plants for } \\
\text { food, hunting of wild animals, } \\
\text { sales of livestock to buy } \\
\text { grains, migration of young } \\
\text { men to work in Nigeria, and } \\
\text { borrowing from people in } \\
\text { the community to buy grains }\end{array}$ & $\begin{array}{l}\text { Effective } \\
\text { when the } \\
\text { drought } \\
\text { was not } \\
\text { severe }\end{array}$ & $\begin{array}{l}\text { Food aid - few bags of } \\
\text { sorghum, groundnut, and } \\
\text { cowpea were given to each } \\
\text { household and few bottles of } \\
\text { cooking oil and biscuits. The } \\
\text { state also gave loan to some } \\
\text { households to buy food }\end{array}$ & Very effective & $\begin{array}{l}\text { Food aids from the World } \\
\text { Food Programme and } \\
\text { Catholic Relief Service }\end{array}$ & $\begin{array}{l}\text { Very } \\
\text { effective }\end{array}$ \\
\hline
\end{tabular}


actions, livelihood diversification in forms of off-season farming and investment in livestock (mainly small ruminant fattening) were viewed by the respondents as the promising options to reduce their vulnerability to future climatic shocks. These options (off-season farming and small ruminant fattening) are gender-differentiated as they are mainly women's activities in many agro-pastoral communities in West African Sahel (Saqalli 2008). The critical role of women in reducing vulnerability to drought and other shocks can partly be explained by the exodus of many young men from pastoral and agro-pastoral communities into urban centres leaving women and elderly men behind (Saqalli 2008). However, young pastoral and agro-pastoral men in urban centres contribute to the rural economy through remittances to their households (Saqalli 2008).

The external assistance required for community preparedness for future drought/famine included supply of agricultural inputs at subsidized rates, establishment of cereal banks and input shops, digging of wells for off-season farming, supply of feed supplements and veterinary drugs, better access to credit, and training in income-generating activities. The suggested external assistance essentially focuses on institutional support for the agro-pastoral communities and favourable agricultural policy. In all the sites, the participants tend to rely on external assistance as means to reduce vulnerability to future hazards.

\section{Strengths and limitations of participatory vulnerability approach: experience from our study}

The degree of individual participation at the community workshop and focus group discussion in all the three study sites was good, due largely to the skilled facilitator who moderated the meeting despite the challenge of ensuring productive dialogue among multiple local stakeholders (van Aalst et al. 2008). This confirms the important role of the facilitator in participatory vulnerability assessments, which may shape the outcome. However, the facilitator faces the challenge of being independent of the process being facilitated. Despite the good facilitation of the community workshops, it was noted in Gabi and Zermou that women hardly participated in the discussions but the involvement of women in Fakara was good. The facilitator specifically asked some of the women in Gabi and Zermou to talk, but only few of them did so by just assenting to what men had said. This could be attributed to a very strong influence of Islam in these study areas, as they are close to the northern part of Nigeria where there is influence of some radical Islamic groups. Women are generally marginalized in these areas and can hardly talk in public when men speak. When we recognized this problem in Gabi and Zermou, we tried to organize a separate focus group for women but we could not as we did not have

any woman in the project team and a man is not allowed to lead women's group discussion in these areas. This problem faced in Gabi and Zermou raises the potential influence of socio-cultural contexts on participatory vulnerability analysis and the limitation of the applicability of findings from PVA in view of this challenge.

The unanimity of response for most of the issues discussed on vulnerability to drought in the study areas could be a reflection of the actual experiences in the community, but it could also be attributed to the domination of the majority opinions which might have discouraged minority views. However, there were minority views on the severity of drought in the study sites, particularly for drought considered modest by a majority of the participants. The view of the minority respondents is likely based on the effect of the drought on their livelihoods, as the impact on households in a community varies depending on their livelihood strategies, socio-economic profiles, and resource endowments.

One of the strengths of PVA is that it can strengthen linkages between research and local practices, and foster the alliance between the communities and the external agencies, particularly NGOs (Table 4). In our study, at

Table 4 Strengths and weaknesses of participatory analysis of vulnerability

\begin{tabular}{ll}
\hline Strength & Weakness \\
\hline 1. It is empirical and based on & 1. It may reinforce existing power \\
actual observations of current & relationships and inequalities in the \\
climate risks and how communities & community \\
cope with them &
\end{tabular}

2. Allows for a representative participation of stakeholders in dealing with their problems

3. It promotes inclusivity and participation in decision making on community strategies to reduce their vulnerability

4. It can foster local ownership and responsibility for identified strategies or actions to reduce vulnerability

5. It responds to people's own priorities and concerns about the risks/hazards they face

6. It can strengthen linkages between research and local practices, and can strengthen alliance with external agencies that can provide support to reduce vulnerability of the community

7. It facilitates co-learning and capacity building of the local stakeholders to conduct vulnerability assessments

Sources: Roncoli 2006; Tschakert 2006; van Aalst et al. 2008; Fazey et al. 2010;

Brockhaus et al. 2013; Rurinda et al. 2014; Asare-Kyei et al. 2015

2. There is the likelihood of being dominated by few people while those who are shy or with minority viewpoints may not have opportunity to express themselves

3. It still relies on the traditional mechanisms of extractive data collection

4. The problem of scalability of location-specific findings to elsewhere with similar contexts

5. It often requires a skilled facilitator who can manage groups of people and effectively guide the discussion

6. Respondents may not be comfortable in expressing controversial opinions as

confidentiality and anonymity are not assured in a group discussion

7. It may create expectation of external support due to involvement of outside agencies particularly NGOs 
least one NGO participated in the community workshop in each site, as well as representatives from the Ministry of Animal Resources and the Ministry of Public Health, but their presence tended to trigger a long list of requests for external assistance by the community members. The challenge this poses is how to elicit correct information from the community members, while at the same time avoid raising their expectation of external interventions, as this may affect their design of community actions. Again, this requires a skilled facilitator to manage the groups and ensure focus on the issues being discussed.

Other strengths and weaknesses of PVA are presented in Table 4 based on the literature. Our experience from this study confirms most of these strengths and weaknesses. The main weakness of participatory vulnerability assessments is the scalability of findings, as they are often location-specific. Therefore, participatory assessment should be complemented with more rigorous quantitative approaches to enhance applicability of the results from participatory approaches. For example, the response on the severity of drought in the study sites could be validated by the meteorological data.

\section{Conclusion}

The incidence of drought has become more frequent in the last three decades, according to the respondents in all the three study sites. The common features of drought in the study sites included sudden cessation of rainfall, late onset of rainfall, and insufficient rainfall, which led to poor crop yields or complete crop failure. The main impacts of drought on livelihoods of the communities were food shortage, famine, sales of livestock to buy grains, and forced migration of young people. Children, women, and elderly people were the most vulnerable groups to drought. Poor households without livestock were also mentioned as vulnerable to drought as they had no means to buy grain to meet household food deficit. The major coping strategies of the community in response to drought included harvesting of wild plants, sales of livestock to buy grain, migration to nearby towns or neighbouring country, and help from relations. These coping measures were generally seen as ineffective when faced with severe drought. In all the sites, government interventions in the form of food aid were seen as very important in enhancing their ability to cope. However, food aid by the government is not always regular and not well targeted.

Some of the strengths of participatory vulnerability approaches as found in our study include inclusivity and participation of the local stakeholders in decisionmaking on community actions to reduce vulnerability and strengthening of linkages between research and local practices and between the local communities and external agencies that can provide support. Despite these strengths, participatory vulnerability approaches face the challenge of domination by a few people and reinforcement of the existing power relationship and inequalities in the community. The main weakness of participatory vulnerability assessments is the scalability of findings as they are often location-specific. Therefore, participatory assessment should be complemented with more rigorous quantitative approaches to enhance applicability of the results to other locations with similar contexts.

\section{Endnotes}

${ }^{1}$ Drought in this study is defined by informants and as such includes both mild (moderate) and severe droughts with the latter often associated with famine. According to the participants, drought referred to temporary lack of water caused primarily by climate, which negatively affects the agricultural productivity and human society. From this definition, the respondents focused on meteorological drought.

\section{Competing interests}

The authors declare that they have no competing interests.

\section{Authors' contributions}

AAA designed the study and drafted the manuscript. MDT made comments on the manuscript and wrote part of the introduction. AK carried out the field work. All authors read and approved the final manuscript.

\section{Acknowledgements}

This study was part of the project 'Identifying livestock-based risk management and coping options to reduce vulnerability to droughts in agro-pastoral and pastoral systems in East and West Africa' funded by the CGIAR Systemwide Livestock Programme (SLP).

\section{Author details}

${ }^{1}$ International Livestock Research Institute (ILRI), c/o CIFOR, 06 BP 9478 Ouagadougou 06, Burkina Faso. ²Department of Geography, University of Wisconsin, 160 Science Hall, 550 Park Street, Madison, WI 53711, USA. ${ }^{3}$ International Crops Research Institute for the Semi-Arid Tropics (ICRISAT), BP 12404 Niamey, Niger.

Received: 26 February 2015 Accepted: 7 July 2015

Published online: 29 July 2015

\section{References}

ActionAid International. 2005. Participatory vulnerability analysis: a step-by-step guide for field staff. London: ActionAid International.

Adger, WN. 2006. Vulnerability. Global Environmental Change 16: 268-281.

Agrawal, A, M Kononen, and N Perrin. 2009. The role of local institutions in adaptation to climate change. In Social development Working paper 118. Washington: The World Bank.

Asare-Kyei, DK, J Kloos, and FG Renaud. 2015. Multi-scale participatory indicator development approaches for climate change risk assessment in West Africa. International Journal of Disaster Risk Reduction 11: 13-34.

Ayantunde, AA, M Kango, P Hiernaux, HMJ Udo, and R Tabo. 2007. Herders' perceptions on ruminant livestock breeds and breeding management in South-western Niger. Human Ecology 35: 139-149.

Ayantunde, AA, J de Leeuw, MD Turner, and M Said. 2011. Challenges of assessing the sustainability of (agro)pastoral systems. Livestock Science 139: $30-43$.

Barton, D, J Morton, and C Hendy. 2001. Drought contingency planning for pastoral livelihoods, Policy series 15 . Natural Resources Institute, University of Greenwich, Chatham

Bassett, TJ, and C Fogelman. 2013. Déjà vu or something new? The adaptation concept in the climate change literature. Geoforum 48: 42-53. 
Brockhaus, M, H Djoudi, and B Locatelli. 2013. Envisioning the future and learning from the past: adapting to a changing environment in northern Mali. Environmental Science and Policy 25: 84-106

Brooks, N. 2004. Drought in the Sahel: long term perspectives and future prospects. Tyndall Centre for Climate Change Research Working paper no. 61. University of East Anglia, Norwich.

Campbell, DJ. 1999. Response to drought among farmers and herders in southern Kajiado district, Kenya: a comparison of 1972-1976 and 1994-1995. Human Ecology 27: 377-416.

Cannon, T, and D Muller-Mahn. 2010. Vulnerability, resilience and development discourses in context of climate change. Natural Hazards 55(3): 621-635.

Cutter, SL. 2006. The science of vulnerability and vulnerability of science. In Hazards, vulnerability, and environmental justice, 133-150. London: Earthscan.

Deressa, T, RM Hassan, and C Ringler. 2008. Measuring Ethiopian farmers' vulnerability to climate change across regional states. Discussion paper 00806. Washington: International Food Policy Research Institute (IFPRI).

Eakin, $\mathrm{H}$, and AL Luers. 2006. Assessing the vulnerability of social-environmental systems. Annual Review of Environment and Resources 31: 365-394.

Eriksen, SH, K Brown, and PM Kelly. 2005. The dynamics of vulnerability: locating coping strategies in Kenya and Tanzania. The Geography Journal 171: 287-305.

Fazey, I, M Kesby, A Evely, I Latham, D Wagatora, JE Hagasua, MS Reed, and M Christie. 2010. A three-tiered approach to participatory vulnerability assessment in the Solomon Islands. Global Environmental Change 20: 713-728.

Freeman, HA, S Kaitibie, S Moyo, and BD Perry. 2008. Livestock, livelihoods and vulnerability in Lesotho, Malawi and Zambia: designing livestock interventions for emergency situations. Research report 8. Nairobi: ILRI (International Livestock Research Institute).

Hiernaux, P, and A Ayantunde. 2004. The Fakara: a semi-arid agro-ecosystem under stress. Report of research activities of International Livestock Research Institute (ILRI) in Fakara, South-western Niger, between 1994 and 2002, submitted to Desert Margins Program, ICRISAT Niamey, Niger, 95.

Luers, AL. 2005. The surface of vulnerability: an analytical framework for examining environmental change. Global Environmental Change 15: 214-223.

Martin, R, B Miller, A Linstadter, and K Frank. 2014. How much climate change can pastoral livelihoods tolerate? Modelling rangeland use and evaluating risk. Global Environmental Change 24: 183-192.

Miller, F, H Osbahr, E Boyd, F Thomalla, S Bharwani, G Ziervogel, and B Walker. 2010. Resilience and vulnerability: complementary or conflicting concepts? Ecology and Society 15(3): [online]. http://www.ecologyandsociety.org/vol15/ iss3/art11/

Moritz, M, BR Kyle, KC Nolan, S Patrick, MF Shaffer, and G Thampy. 2009. Too many people and too few livestock in West Africa? An evaluation of Sandford's thesis. Journal of Development Studies 45: 1113-1133.

Mortimore, MJ, M Tiffen, B Yamba, and J Nelson. 2001. Synthèse sur les évolutions à long terme dans le département de Maradi, Niger 1960-2000. Working paper 39f. Somerset: Drylands Research.

Nielsen, JØ, and A Reenberg. 2010a. Cultural barriers to climate change adaptation: a case study from Northern Burkina Faso. Global Environmental Change 20(1): 142-152.

Nielsen, JØ, and A Reenberg. 2010b. Temporality and the problem with singling out climate as a current driver of change in a small West African village. Journal of Arid Environments 74(4): 464-474.

O'Brien, K, R Leichenko, U Kelkar, H Venema, G Aandahl, HJ Tompkins, S Bhadwal, S Barg, L Nygaard, and J West. 2004. Mapping vulnerability to multiple stressors: climate change and globalization in India. Global Environmental Change 14: 303-313.

O'Brien, K, S Eriksen, LP Nygaard, and A Schjolden. 2007. Why different interpretations of vulnerability matter in climate change discourses. Climate Policy 7: 73-88.

Opiyo, FEO, OV Wasonga, and MM Nyangito. 2014. Measuring household vulnerability to climate-induced stresses in pastoral rangelands of Kenya: implications for resilience programming. Pastoralism: Research, Policy and Practice 4: 10.

Prokopy, LS, AS Mase, and R Perry-Hill. 2013. Assessing vulnerabilities and adaptation approaches: useful to usable tools. Earth Systems and Environmental Sciences, Climate Vulnerability 2: 129-137.
Ribot, JC. 2011. Vulnerability before adaptation: toward transformative climate action. Global Environmental Change 21: 1160-1162.

Ricci, L, B Sanou, and H Baguian. 2015. Climate risks in West Africa: BoboDioulasso local actors' participatory risks management framework. Current Opinion in Environmental Sustainability 13: 42-48.

Roncoli, C. 2006. Ethnographic and participatory approaches to farmers' response to climate predictions. Climate Research 33: 81-99.

Roudier, P, B Muller, P d'Aquino, C Roncoli, MA Soumare, L Batte, and B Sultan. 2014. The role of climate forecasts in smallholder agriculture: lessons from participatory research in two communities in Senegal. Climate Risk Management 2: 42-55.

Rurinda, J, P Mapfumo, MT van Wijk, F Mtambanengwe, MC Rufino, R Chikowo, and KE Giller. 2014. Sources of vulnerability to a variable and changing climate among smallholder households in Zimbabwe: a participatory analysis. Climate Risk Management 3: 65-78.

Saqalli, M. 2008. Populations, farming systems and social transitions in Sahelian Niger: an agent-based modeling approach. PhD thesis. Université Catholique de Louvain, Belgium.

Saqalli, M, B Gérard, C Bielders, and P Defourny. 2011. Targeting rural development interventions: empirical agent-based modeling in Nigerien villages. Agricultural Systems 104: 354-364.

Saqalli, M, CL Bielders, P Defourny, and B Gerard. 2013. Reconstituting family transitions of Sahelian western Niger 1950-2000: an agent-based modeling approach in a low data context. Cybergeo: European Journal of Geography. doi:10.4000/cybergeo.25760.

Sen, A. 1981. Poverty and famines: an essay on entitlement and deprivation. Oxford: Oxford University Press.

Smit, B, and J Wandel. 2006. Adaptation, adaptive capacity and vulnerability. Global Environmental Change 16: 282-292.

Thornton, PK, J van de Steeg, A Notenbaert, and M Herrero. 2009. The impacts of climate change on livestock and livestock systems in developing countries: a review of what we know and what we need to know. Agricultural Systems 101: 113-127

Tiffen, M. 2001. Profile of demographic change in the Kano-Maradi region, 1960-2000. Working paper 24. Somerset: Drylands Research.

Tschakert, P. 2006. Views from the vulnerable: understanding climatic and other stressors in the Sahel. Global Environmental Change 17: 381-396.

Turner, MD. 2000. Drought, domestic budgeting, and changing wealth distribution within Sahelian households. Development and Change 31: 1009-1035

Turner, BL. 2010. Vulnerability and resilience: coalescing or paralleling approaches for sustainability science? Global Environmental Change 20: 570-576.

Turner, MD, and PP Hiernaux. 2002. The use of herders' accounts to map livestock activities across agro-pastoral landscapes in semi-arid Africa. Landscape Ecology 17: 367-385.

UNEP. 2002. Global Environment Outlook 3: past, present and future perspectives. United Nations Environment Programme (UNEP): Nairobi.

Van Aalst, MK, T Cannon, and I Burton. 2008. Community level adaptation to climate change: the potential role of participatory community risk assessment. Global Environmental Change 18: 165-179.

Vogel, C, SC Moser, RE Kasperson, and GD Dabelko. 2007. Linking vulnerability, adaptation, and resilience science to practice: pathways, players and partnerships. Global Environmental Change 17: 349-364.

Watts, M. 2013. Silent violence: food, famine and peasantry in northern Nigeria. New Addition Aufl. Athens, GA: University of Georgia Press.

Watts, MJ, and HG Bohle. 1993. The space of vulnerability: the causal structure of hunger and famine. Progress in Human Geography 17: 43-67.

WFP. 2005. Analyse de la sécurité alimentaire et de la vulnérabilité. Collecte et analyse des informations secondaires. Rome: World Food Programme (WFP).

Wisner, B, P Blaikie, T Cannon, and I Davis (eds.). 2004. At risk: natural hazards, people's vulnerability and disasters, 2nd ed. London, UK: Routledge. 